\title{
Chapter VI: From Practice to Theory
}

The many different cases presented so far show a diversifying toolbox that is used for multiple purposes. But how can the diversity of practice be reflected in diversity of theory, and how can it in turn inform future cases? A process of reflective learning is crucial in order to both avoid the settling in of orthodoxy and keep advocacy open towards yet unknown possibilities.

To draw out the various insights useful for further development in both theory and practice, I want to look at some court cases that already show, in practice, some of the theoretical tensions I have pointed out. In particular, these clarify the essential role of the state in rights of nature. After doing this, I will discuss a series of crucial ideas for the rights of nature that need to be rethought. I will start with looking one last time at the relationship between indigeneity and rights so as to open up new avenues for Indigenous empowerment that look beyond the concept of right. I will re-examine the idea of legal person with a particular focus on the person as a model for what counts (legally, politically, ethically). Indigenous thought offers plenty of resources for decentering the person in legal and political thought.

The last sections think about what a critical engagement with rights suggests for further practice. I argue that the crucial question is not what rights nature may have, but rather who is entitled to speak for nature. In other words, the role of political representation is central in all rights of nature practice and should be better reflected in theory. Lastly, I will examine whether the rights of nature can, at this point in their history, count as a movement. The claim that all cases so far are part of a movement is so ubiquitous 
as to need no particular reference. The expression "the movement for rights of nature" has become a habit for advocates and commentators. I will examine in detail whether this claim is warranted, and I will argue that it risks hiding the diversity of practice in favor of ecotheological orthodoxy. In order to restore diversity, we need to think much more critically about what makes a movement, and how movements themselves need to remain open to unpredictable possibilities.

\section{Some Court Cases}

Most rights of nature laws so far have been untested in court. The discussion developed in this book should help anticipate the diversity of cases that will ensue in the next decades, with results ranging widely. The expected, and so far witnessed, variation in results follows from the conceptual and practical diversity of rights for nature as well as from the different contexts in which they have appeared. The purposes motivating different legal provisions vary, and therefore their application will as well. Even if there haven't yet been a lot of legal cases to speak of, some of the earliest installments of rights of nature have been tested in court. This is the case in Ecuador, where there are already several court cases that can be examined. And they already show the practical consequences of many of the theoretical ambiguities explored.

The most widely covered case so far is also the first one in the country, namely the protection of the rights of Vilcabamba river. The plaintiffs sued the municipal government for having modified the course of the river through a road construction project. The municipal government undertook the expansion project without having the necessary environmental impact assessments. The resultant material from the construction project was dumped in the river, and this caused a modification of its course, which then resulted in flooding the downstream property of riparian landowners. These sued the municipal government using the constitutional rights of nature provisions adopted in 2008 . 
The landowners could have also sued for damage to their property, but they did not, instead choosing the mechanism of nature's rights. As I have argued in Tănăsescu (2016), the wide standing that the constitution grants for the legal representation of nature is shown to also have a connection with the issue of property. Though advocates routinely claim that the rights of nature are opposed to property rights, this is not necessarily so. The Loja provincial court recognized the legal standing of the riparian owners also because they were directly interested in the fate of their property, now partly flooded. This makes perfect sense, and other legislation (for example, the New Zealand cases) already takes into account the special relationship that obtains between places and their owners.

The local government was ordered to remedy the harm caused to the river and issue a public apology. The remediation has been quite slow to materialize. In principle, the river is supposed to be turned back to the state that the riparian owners preferred. However, if restoration is to be understood strictly, then the rights of nature could also have been used against riparian owners, for the return of the river to some earlier state. However that may be, the potential tension between human and nature's rights was resolved by the judge apparently in favor of nature. He explicitly stated that the right to a healthy environment is more important than the right to a better road, even though this is weighing two different kinds of human rights against each other. In this case, the judge imposed this particular hierarchy of rights, but there is nothing definitive in the Ecuadorian constitution that obliges judges to reach the same decision elsewhere. The constitution in fact states that all of its many rights are on the same level of importance. This is impossible to implement in practice, where decisions will have to prioritize some rights over others, thus leaving ample room for interpretation. $\mathrm{Hu}-$ man rights jurisprudence especially has as a core task the balancing of rights.

This wide interpretive space is even better exemplified in another case in Ecuador, namely the Mirador case of 2013. Here, an alliance of Indigenous Groups and environmental NGOs sued a mining conglomerate and the state for violation of nature's rights in a planned mining operation in the Cordillera del Cóndor, a hyper 
biodiverse region of the country and also home to Indigenous populations. The plaintiffs sued because the mining concession was approved by the relevant ministries, and they alleged that this concession would violate several rights given by the constitution, including the rights of nature. They also claimed that the precautionary principle enshrined in the constitution would be violated by the planned mining activities.

Unlike in the Vilcabamba case (which, it is important to keep in mind, was a small-scale project of little national importance), the company planning to do the mining - Ecuacorriente S.A. - had undertaken all necessary environmental impact studies, which were approved by the resource and environmental ministries. The judge ruled that, because all of the necessary documentation had been correctly filled, there was no basis for the plaintiffs to assume rights were being violated. Furthermore, the alleged violation was supposed to happen in the future, and therefore the plaintiffs had no basis to claim that it would in fact happen.

The judge interpreted the buen vivir doctrine enshrined in the Ecuadorian constitution as requiring a level of resource extraction and argued that there is no inherent reason why such extraction cannot be done in an environmentally responsible manner. Here, the weighing of nature's rights against the human right to development was done in favor of the latter, clearly understood as the prerogative of a modern state that needs to be integrated within a global economic system predicated on consumptive lifestyles. Although this decision was obviously unpopular with rights of nature advocates, it is no faultier than the Vilcabamba one. Both of them operate within the wide margin of interpretation that the constitution makes possible. Considering these cases together, it becomes clear just how important the political dimension of the rights of nature is. In fact, we can only understand such cases by thinking about them as instances of political weighing of interests that, in any particular case, may run in incompatible directions.

To this end, the important role played by the environmental assessment documents is telling. In the Vilcabamba case, it was their absence that occasioned the lawsuit and figured greatly in the decision of the court. In the Mirador case, their existence - in fact, the 
defendant's compliance with the law - also proved crucial, but in the opposite direction. CELDF, the American organization instrumental in codifying the Ecuadorian constitutional provisions, has long argued that granting rights to nature would overcome the role of the state as mere regulator of environmental harm. In their view, things like environmental impact assessments simply tell companies how they can be allowed to do damage. The rights of nature, they argue, would be a solution to this problem. In practice, however, these kinds of impact assessments prove to be very sticky indeed. In the context of already existing rights of nature, judges will still have to decide whether the defendants have complied with existing law (which requires impact assessments). If they have, it will still be very hard to forbid resource extraction, especially because the neoliberal state committed to it, nature's rights notwithstanding. As I argued previously, the state is comfortable with rights and knows how to bend them as it suits political and economic elites.

Though this particular case doesn't immediately show the problems raised by nature's right to restoration, it does open up a speculative space where these problems can be explored. In philosophical debates on the meaning of restoration, one of the greatest issues identified by philosophers (see Elliot 2008, Katz 2009, 2012) has been the problem of "moral hazard". Restoration started its life as a technical solution to industrial disruption of environmental conditions. It really took off in the late $20^{\text {th }}$ century, when the belief that humans can turn environments back really took hold, largely because of advances in restoration techniques. However, the idea that one can return a place to a previous state in a sense incentivizes extractivism, because it is now possible - at least on paper - to extract while only temporarily disrupting. This is the issue of moral hazard, namely that restoration can act as an incentive, as just another box to tick in order to be allowed to progress with the project of modern development.

While the idea of moral hazard is not the only way of assessing restoration, it is a real problem in baseline-specific projects. Where the target of restoration is a particular past composition of the environment (known as a baseline), it is easy to see how extractive industries can promise to turn back the clock. This, in fact, 
already routinely happens, and whether such promises are kept or not is then subject to lengthy litigation. ${ }^{1}$ Additionally, only large industry players can even promise to restore, precisely because of the costs involved and the technical expertise required. Thus, enshrining a right to restoration without specifying what this means immediately opens the possibility of empowering extractive industries. This is implicit in the Mirador case, in which the judge obviously thought that mining can be done in a responsible manner, which includes the remediation of a site after extraction is complete. In future cases, this use of restoration may as well become explicit.

The role of the state is clear in the Mirador case, particularly because the sentence was specifically justified in terms of the duty of the State to "develop" and, in so doing, to protect the liberal rights of its citizens (some of whom count more than others). The inherent tensions in the liberal rights concept and its constructive relation with modern nation states can be contemplated here in its practical effect. These effects are also in line with the political moment. Rafael Correa, president of Ecuador at the time of this case, made clear his position that development is paramount and that it can be pursued whilst respecting the environment. Extractive industries under the Correa government expanded at an unprecedented rate (Lalander 2014), and they were explicitly justified through both nationalism (the nation state, not corporations, must reap the benefits) and progressive policies of redistribution (funding healthcare, education, infrastructure for the poor).

This, what Gudynas (2009) has called progressive neo-extractivism, functions very well with a panoply of rights that it selectively activates. In this selective activation, several things help greatly. On the one hand, the vague standing requirements of the Ecuadorian constitution are incredibly helpful. On the other, the gendering of nature, as I have argued previously with support from the work of Tola (2018), works in favor of extractivism.

The first point is best seen in the use of rights for nature by the Ecuadorian state itself to clear the way for large-scale mining. The state, this time as plaintiff, sued artisanal miners and argued that 
"the illegal mining was polluting the Santiago, Bogotá, Ónzole and Cayapas rivers, thereby violating the rights of nature. Two months later, the Second Court of Criminal Guarantees of Pichincha issued the injunction 'for the protection of the rights of nature and of the people"' (Daly, 2012). Subsequently, army personnel cleared the area of artisanal miners (largely impoverished populations forced into precarious labor) and confiscated or destroyed their property. At the same time, the national government expanded its mining concessions to both state and multinational actors. This kind of use of the rights of nature may seem like a perversion to advocates, but it is not: It is well within the logic of what the Ecuadorian constitution provided bases for.

The second point - the problematic gendering of nature as Mother Earth - is better seen by switching to Bolivia. There this gendering has been explicitly used in relation to resource generation (and, logically, extraction). Generation is the counterpart of the nurturing aspect of femininity stereotypically applied to motherhood. Rights of nature advocates routinely use this portrayal as if it were an unproblematic fact. In Bolivia, as in Ecuador, the government of Evo Morales has expanded natural resource exploitation with largely similar justifications (development and progressive redistribution of the supposed benefits). And it has specifically used the image of Mother Earth in order to achieve this.

Morales, for example, has inaugurated the first Chinese pilot plant for producing lithium-ion batteries, an increasingly crucial part of the global drive towards "green growth". These batteries are fundamental for, among other gadgets, electric vehicles, which governments the world over are promoting at increasing rates. Morales framed the lithium reserves of Bolivia as a generous gift of Mother Earth, part and parcel of its nurturing its people. Lalander (2014, 169) quotes him as saying that "Bolivia has the largest lithium reserves of the entire world, that's our Mother Earth. [...] You could not imagine how Mother Nature provides us natural resources". Wouldn't it be foolish, the implication goes, to leave those underground? Wouldn't it be a betrayal of the gifts of nature, that could be used for socially progressive purposes? It is easy to be outraged 
at this kind of rhetoric, but it is in fact already sanctioned by the conceptual apparatus explored throughout this book.

There are several other Ecuadorian court cases currently ongoing. So far, of the 13 Ecuadorian cases that have reached final decisions and that Kauffman and Martin (2017a) document, none of those brought by the government were lost. It remains to be seen whether this kind of state bias continues, but the kinds of issues brought out at the intersection of theory and practice are there to stay (at least until the law changes), and they offer great learning possibilities for what is an experimental and evolving practice.

One could expect similar patterns to emerge in future cases where ecotheological rights for nature have been enshrined. The wide variation in outcome between the various extant court cases ${ }^{2}$ reveals the problems inherent in a formulation of nature's rights based on a universal subject (nature as person) and wide standing. It remains an open question how other cases, from New Zealand to Colombia, as well as future ones, will play out in practice. For now, there isn't enough empirical evidence to decide, but based on the theory explored I would expect, particularly in the New Zealand cases, further empowerment of Māori groups as well as selective resource development, which does not inherently contradict Māori views. The kind of implementation explored in Ecuador and Bolivia is very difficult to pull off under the New Zealand conditions, which all but preclude it. This is itself an important lesson: paying attention to detailed representative arrangements is very important for what nature's rights may end up doing.

\section{Indigeneity and Personhood}

Though Indigenous People started out as allies of the Ecuadorian and Bolivian governments, they soon fell out. This is a continuation of the always antagonistic relationship between Indigenous communities and the nation state. Ever since the earliest history of colonization, Indigenous People have had to adapt to the increasingly 
powerful presence of the state while keeping alive traditions and ways of knowing and thinking that are radically different from the premises of nationalism. Even though the rights of nature initially appeared to bolster indigenous rights, the very concept of rights itself should have alerted advocates to more ambiguous results. Indeed, Indigenous communities in Ecuador and Bolivia have been confronted by yet another case of the state selectively using rights to further its agenda, often at their expense.

The supposedly inherent relationship between the rights of nature and indigeneity has become a trope of scholarship and news coverage. These rights are often presented as emanating from, or translating, indigenous thinking. I have already argued against this view (also see Tănăsescu 2020) extensively. ${ }^{3}$ Here, I want to complement that argument with one last element which is revealed by the variation in practical applications of rights for nature laws. The legal person status of nature is very often seen as the bridge between indigenous and western legal conceptions. In the case of Mother Earth, for example, the case for its supposed personality has been forcefully made, and also forcefully tied to indigeneity. However, the way in which indigenous thinking conceptualizes the environment is much more diverse than that and, as I will argue, is not particularly helped by the notions of person or personality.

Critical legal scholarship has started to uncover the moral roots of the concept of legal person as well as the tautological relationship it has with the concept of rights. Costas Douzinas, for example, argues that "for the liberal philosophy of personhood, human rights belong to 'normal' people" (in Gearty and Douzinas 2012, 65). He goes on to show that normality is itself constructed in such a way as to exclude undesirable people. Joanna Bourke (2011), in What it Means to be Human, shows this in detail, demonstrating how ideas of normal personhood have been used throughout the history of liberalism to exclude women, immigrants, and racialized minorities.

But see O'Donnell et al (2020) for a nuanced view of Indigenous involvement in the rights of nature. Despite the nuance, I think most of my critique still holds. 
Douzinas further shows that this kind of exclusion is not an aberration of rights theory, but the logical application of its tautological identification of rights with a particular kind of person. Today, it is undeniable that "immigrants, refugees and the poor" are not part of the rights paradigm, even as this paradigm has become the only ideology available in our otherwise post-everything world.

Naffine (2003, 2011), Grear (2013), and Davies (2012) lend further support to the view that the idea of legal personality and its automatic implication in rights theory and practice, derives from a standard imposed by the "normal human individual". Arstein-Kerslake (2017) has shown how the model legal person has routinely excluded people with disabilities or with identities that differ from the moral standard inherent in the concept. What I also want to point out is that the idea of conformity to a standard, in the history of liberalism, understands the person as an individual. The rights of the legal person are therefore primarily the rights of an individual qua individual.

It is in the individuality of the person that liberalism finds the foundation for its rights claims. It is the individual that is inviolable, that has rights, and that lends its atomic separation from everything else to the notion of the person. In Western philosophy, the prototypical liberal subject is the Cartesian individual, separated from everything else and alone with his thoughts, through which he comes to know his need and desires. "This conception of personhood becomes the basis for methodological and moral individualism: society exists for the promotion of individual purposes" (Gearty and Douzinas 2012, 71).

Though it is harder and harder to state this today, rights are fictions just as the idea of legal personality is one. To paraphrase Douzinas, there is no right to rights. In other words, rights are not discovered, but invented, proclaimed, given. To make this argument is not to say that rights have no function, or no basis whatsoever, but it is to say that they are not the panacea they claim to be simply because they are grounded in the individual human body.

As Samuel Moyn argues, in The Last Utopia (2012), the history of human rights in particular "illustrates the persistence of the nation state as the aspirational forum for humanity". During the second 
half of the $20^{\text {th }}$ century, competing ideologies, particularly utopian ones, lost their popular legitimacy, culminating in the post-Cold War era. "It was the crisis of other utopias that allowed the very neutrality [of human rights ...] to become the condition of their success" (213). This supposed neutrality is precisely the claim that rights are recognized and that they are as much moral as political categories.

This moralism of rights, which has been adopted by the rights of nature, came into the contemporary world as a form of anti-politics. In time, though, this stance - as all anti-political ones - became untenable, because "they could not remain wholly noncommittal towards programmatic endeavors" (213). As human rights inevitably moved towards ideology, replacing other dying utopias, they were mythologized as having always existed, a claim that is patently false. Ideologically, however, its empirical falsity matters little, as ideologies must take the move towards universality in order to shore up their program. In the early $21^{\text {st }}$ century, they became fully incorporated with the power of the state, a process particularly visible through humanitarian interventions, predicated on incredible violence, in order to shore up human rights. In this way, they became both "the means and object" of politics, a process which moralizes politics such that its capacity to mediate conflict is severely diminished (Douzinas 2007, 7). Or as Kelefa Sanneh (2021) argues, commenting on Jamal Green's book How Rights Went Wrong, "the endless search for 'fundamental' rights inevitably makes disputes [...] more intractable".

The biggest problem with moralism is that it imparts an unjustifiable confidence because one is convinced of possessing the truth. This is the danger of certainty at a time when what is needed is precisely the ability (necessarily cultivated through careful and committed practice) to navigate, and live with, uncertainty (also see Tănăsescu 2022). The moralism of the rights of nature stems directly from the moralism of human rights, a phenomenon that really came into its own when rights became tools of the state, even though they were born in opposition to it. The radical core of a universal doctrine of rights - the forging of identities around universal forms of equality - became hollowed out by their becoming ideological tools through which violence is often legitimized. 
I have argued that the rights of nature cannot help but participate in the liberal rights expansion that has spawned them to begin with. It is perhaps telling that, in the extant cases with the greatest and, crucially, deepest Indigenous involvement (Te Urewera and Whanganui), rights-talk is minimized as much as possible. Particularly in Te Urewera, even the idea of personhood is minimized, and the new legal construct is mostly referred to as a "legal entity". Here, theory could help future practice by asking it to reflect more on the availability of "legal entity" as an alternative to the conundrums that personhood throws up. These conundrums will manifest when we pass from human to nature's rights, because 'nature' is the same kind of totalizing abstraction that 'humanity' is. It may never be the case that all humans belong to the category of humanity because that process of inclusion is not a merely legal one, but one of political and social economy.

Similarly, and despite the totalizing nature of the Universal Declaration of the Rights of Mother Earth, not everything will belong to the category 'nature'. Pests will continue to exist, pathogens also, viruses and undesirable animals will continue to be exterminated. It is not in the power of the law to amend this situation. But it is in its power to reflect on its conceptual vocabulary and to see how it may be complicit in certain unintended consequences.

The world of individuals hermetically sealed within their heads, where they can rationally know their interests, is the world of modernity, one that is spatially flat and whose time is that of progressive linearity or development (understood, among others, in terms of the expanding rights of the individual). This world was unknown, in Europe as well as elsewhere, before the advent of modernity, which invented it. This is not, in other words, an indigenous world, and it shares very little characteristics with it. Indigenous thinking, despite its great diversity, does not tend to be focused on binary oppositions (society/nature, individual/group, and so on), but rather tends to be relational. In relational terms, what counts as being a subject varies greatly, and the idea of the person modelled on individual, 'normal' humans is entirely absent.

Instead, the world consists of mutating relationships that give rise to various subjectivities, some more enduring than others. Cru- 
cially, it consists of alliances and groups that travel through space and time, as visible through the treatment of various embodied spaces as kin (and therefore connected to the present through genealogical lines). This treatment of non-humans and non-related humans as kin is also indicative of the relatively weak role that nativist criteria play in indigenous thinking. Belonging to a place (unlike in the colonial imagination) is not only about birth, but rather about what one does and therefore how one relates to a series of environmental beings. The possibility of relating to the environing world in generative ways is not an ethnic one, but an ethical one. ${ }^{4}$

The study of what the world consists of is known in philosophy as ontology, and indigenous ontologies, as Viveiros de Castro has argued, are not simply descriptions of one same world but rather of completely different worlds. In their interaction with colonial modernity, indigenous worlds have consistently had to "translate" themselves, that is to say to adopt and adapt to a world that is not their own. In practice, this has also meant that Indigenous People have had to adopt the terminology of rights through which to interact with the state. But, as I have argued throughout, that terminology hides the power of the state to discount those subjects that do not, for whatever reason, possess the characteristics of the desired "normal person". Today, we are living through a moment that offers new possibilities for legal pluralism and hybridization, and

4 Though this argument is seldom explicitly made, it is supported by philosophical explorations of some indigenous thought. For example, Anne Salmond (2017), in recounting the early history of Māori - Pakeha (white settlers) relations, shows how the first fifty or so years of contact were dominated by Māori tikanga, because Pakeha were de facto guests that did not have the demographic dominance that would later allow the rise of a settler state. In this early period, many guests became 'related' to their Māori hosts by learning the language and generally adopting tikanga. This indicates that the possibility of belonging was not primarily dictated by birth. Similarly, the ritual recitation that Māori speakers engage in before speaking publically (whaikōrero) can draw on all sorts of genealogical lines, most of which are not blood lines, but ones of alliance. This plasticity again lends credence to the interpretation of genealogy in non-nativist terms. 
it matters greatly that this moment does not end up reproducing the power differentials that have always characterized Indigenous - state relations. This is why it is important to realize how much of a compromise legal personhood and rights are and to ask what other conceptions, stemming from other worlds, we may work with going forward.

For example, on an ontological level, Amerindian philosophies consider subjectivity (subjective experience) - not matter or material properties - to be what connects all beings. In other words, "the manifest bodily form of each species is an envelope (a "clothing") that conceals an internal humanoid form" (De Castro 2019). This deep form of anthropomorphism - literally, everything has interiority - sustains a relational ontology steeped in what Marisol de la Cadena $(2010,341)$ calls "earth-practices", defined as "relations for which the dominant ontological distinction between humans and nature does not work". The reason is two-fold: firstly, it is relations that are primary and, secondly, it is subjectivity that connects all beings..$^{5}$ In many Amerindian philosophies, Andean ones included, there is one humanity and there are many natures, a view that de Castro calls multinaturalism.

"The core issue, once again, is whether humans share in common with nonhumans the body or consciousness, and by that measure, even efforts against anthropo-centrism in environmental philosophy come up naturalist: either by conferring rights only to animals developed enough to be sentient or by arguing that we are responsible for life and abiotic elements because of our physical interdependence with them" (Skafish 2016b, 79). Animist philosophies posit consciousness as the unifying substance tying all forms of life together, and therefore it throws up radically different problems than the naturalism that still informs eco-anthropocentric debates. For example, the problem of life's necessity to consume life is deeply troubling in the context of shared interiority because

5 "Other-than-humans include animals, plants and the landscape" (De la Cadena 2010, 341). 
the consumption of any flesh becomes in a sense cannibalistic, requiring careful ritualization for the transgression not to be fatal. As Descola asks in light of this analysis, "do such observations not indicate that it is high time to ask whether ecological politics can really be undertaken on the basis of nature alone, and if the actual and potential actions of other collectives might somehow be needed, and even somehow practicable, by moderns as well?" (In Skafish 2016b, 79).

In the text of the Ecuadorian Constitution, Pachamama is an indigenous other-than-human figure that erupts in the political space of the state. However, the equivalence in the constitutional text between this figure and Nature - including in the Articles that grant rights to nature - is deeply problematic, as it forces the radical potential of an indigenous led politics into the molds of modernist ontology. In particular, the constitutional text falls prey to the Western obsession with totality, visible in the rendering of Pachamama as universal Nature, Earth as such, if somewhat animated by Amerindian 'beliefs'. The Constitution manages to construct nature on the model of the human person, whereas indigenous philosophy, through its multinaturalism, universalizes the interiority of the human experience (everything has a life of its own) and the dynamism and openness of material forms (and everything changes). From this perspective, it is the concept of a stable human person (with intrinsic characteristics and values) that can be destabilized by modelling it more closely on the dynamism and fundamental openness of nature. Instead, the rights of nature in the Ecuadorian case reinforce a Western view that attaches to nature the universality which it had previously attached to human rights. The possibility of allowing indigenous ontology to disrupt the very notion of universality seems, here, partly foreclosed.

Te Urewera, out of all cases so far, comes closest to ontological mixing on an equal footing. It remains telling, however, that it is not in Te Urewera Act itself that Māori ontology takes the lead, but rather in the management plan, Te Kawa o Te Urewera. There, as discussed in Chapter 4, the very idea of the person is subverted and, instead, the focus is on relationships of reciprocity with the 
environing world. This world is very specific, and it is precisely that ability to pay attention to specificities and get to know them deeply that has nurtured indigenous cultures from time immemorial. This capacity has been widely lost through modernity, which is why Te Kawa lucidly speaks of the need that Tūhoe themselves have to relearn to pay attention to their specific environment. The lessons that this case has for future rights of nature practice are still to be drawn, but theoretically it has already cut a new and promising path.

I do not mean to deny the effort that Indigenous People have put into achieving greater legal pluralism. Quite the contrary, that effort needs to be recognized on its own terms, not always 'translated' into western conceptions! And if we start doing that, we begin to see how what appears as an emancipatory expansion of rights may be, from the perspective of those that have never counted as full persons under liberal conditions, a further solidification of oppressive power. The opposition of Indigenous People to the concept of the state is not only philosophical, but political as well. This can be seen through the origins of the international movement of Indigenous Peoples, which has come about both through and against international bodies such as the UN system.

Ronald Niezen (2003) argues that the notion of Indigenous Peoples was itself created through the World War II expansion and internalization of human rights discourses. There is no doubt that the international movement for Indigenous Peoples was first and foremost spearheaded by Indigenous activists themselves, but the very consciousness of a common fate at the hands of settler powers was a relatively late achievement that incentivized international cooperation among different peoples. The sedimentation of indigeneity as a category referring to particular people was created through a reiterative interaction between external gazes and internal identity formation. In other words, the process of colonization and the subsequent transformation of world order through the ascendancy of the nation state interacted decisively with indigenous societies that were routinely marginalized. This is also the case in the very creation of an international indigenous identity.

The variety of experiences within Indigenous societies is seen in the difficulty of a unified definition of what constitutes indigeneity. 
Despite the lack of such a definition, several common features appear, in particular the common destruction of traditional heritage at the hands of colonial powers. Indigenous identity is united around a terrible loss. The multiplicity of indigenous positions is further unified by the "absence of centralized dogma. Its main ideas [as reflected through international fora] coalesce within a large number of micronationalism and micro-orthodoxies, each a discrete movement oriented toward small communities or regions [...]. Indigenism involves reinvigoration of the comfort and color of local traditions with the safety-in-numbers effect of a global movement" (Niezen 2013, 13).

This is to say that an international Indigenous identity is in a sense forced by the dominance of nation states both in local politics and, indisputably, on the international arena. Politically then, a wide variety of different kinds of societies have had to coalesce around an international indigeneity that, despite this necessity, itself retains a commitment to a kind of inner diversity that is radically opposed to the homogeneity, and the homogenizing force, of states. The partial adoption of rights language on the international arena is a pragmatic accommodation of dominant power relations. But a closer look at what exactly the international indigenous movement claims to want reveals that it does not consistently, or even primarily, ask for equal rights, but rather for self-determination such that the small microhistories that Niezen talks about can be given practical purchase.

That is the radical core of Indigenous Peoples claims. And that is precisely the claim that states neutralize through rights. In the case of Te Urewera, the issue of full tikanga authority was taboo, because it would lead to fears of secessionism among an overwhelming settler majority. It would also pose existential question for the unified state of New Zealand and create precedents that would risk radically transforming its shape towards unknown configurations of power sharing. The Ecuadorian constitution, for example, though widely commented upon as radical in its empowerment of Indigenous People, clearly states that "The indigenous communities, pueblos and nationalities, the afroecuatorian pueblo, the montubio pueblo and the comunas form part of the Ecuadorian State, one and indivisible" 
(art. 56). It is the state that is one and indivisible, and the furthest it will go in relation to colonized populations is to recognize their equal status as rights bearers. Indeed, "the greatest duty of the State consists in respecting and enforcing the respect of the rights guaranteed in the Constitution" (art.11/9).

With each successive wave of national solidification around rights expansion, different possibilities are shut out. Consider again the right to restoration that has become a staple of rights of nature theory and practice. In Andean, as well as Māori, thinking, the beings that are constituted through relations are in flux; they change and adapt to new circumstances and new relations. Therefore, it is not a 'nature out there' that is worshiped as an unchangeable form. Rather, Amerindian philosophies posit environmental relations in terms of reciprocal exchanges, as do Māori ones. Through these iterative exchanges, beings continuously mutate. It is not surprising that radically place-based philosophies would also see the world as highly dynamic, because careful observation of the world reveals precisely that fact. So, something like a right to be restored needs to at least be specified in terms of what restoration may mean. If it is taken to mean a return to a 'pre-disturbance' form (baseline restoration), this kind of right can easily be used by the state to further disempower communities, as I have already shown.

Restoration, as I have argued elsewhere (Tănăsescu 2017, 2022), needs to itself be understood in relational terms and therefore in terms that let indigenous ontology lead. Restoration in the Anthropocene can no longer be about returning to some previous state but rather about returning to meaningful relations with particular places. The recurrence of an unspecified right to restoration in different cases also encourages people to think about rights as applicable to 'untouched' places, exactly the kinds of places that colonial nations had designated as Indigenous reserves. But in a world that is increasingly urban, and in any case increasingly humanized, there is an urgent need to think about what the rights of nature may mean in those settings as well, and what a right to restoration may mean in a densely populated environment. These are all issues that 
will have to be ironed out in the future, but in order to do so it is important to flag them as worthy of attention to begin with.

\section{The Rights of Nature as Representation}

I have argued for some time (Tănăsescu 2013, 2016, 2020, 2021) that the rights of nature are unintelligible without thinking about them as a process of politically representing nature. A nature with rights becomes, first and foremost, a political subject, just like a corporation with rights does. I will not repeat the details of this argument, which can be found elsewhere. Instead, I want to sketch its importance for critically examining rights of nature and draw out some of its implications.

Formally speaking, the rights that nature may receive have to be represented by someone. But this formal requirement has no purchase whatsoever unless this representation is also institutionalized in some form. This is to say that rights of nature cannot be an end in themselves or a self-implementing solution. Simply granting rights to an entity that cannot defend them on its own is useless unless the necessary aspect of representation is given a practical outline. This is partly why, in the cases of Ecuador and Bolivia, the representation of nature is prone to partisan abuse: There is no mechanism of representation mandated by these laws, so anyone can bend them to their particular interest. Similarly, in the Indian cases, the mechanism of representation - affording guardianship to local authorities - was so shoddy that the putative representatives themselves refused to do the job.

Focusing on representative arrangements makes it possible to ask why rights are granted to nature in any particular case. The orthodox answer is that they are granted, in every case, in order to achieve environmental protection. This should ring hollow by now. I don't doubt advocates' good intentions, but I think I have shown in detail how these do not translate into guarantees of environmentally friendly results. Instead, I have demonstrated that the rights of nature are inevitably intertwined with pre-existing power relations. Thinking about them as mechanisms of representation allows this 
aspect of power to come to the fore and therefore to determine how laws are written. If, indeed, they are to be written for environmental protection, then this needs to be carefully thought out in terms of who has the moral and political authority to oversee such protection.

In the most innovative cases so far, Te Urewera and Whanganui, environmental protection was not the main motivator. In both cases, classic environmental institutions, like conservation ministries, were sidelined and power given to other groups that may or may not choose similar goals. From a Māori perspective this makes sense, because from their ontological standpoint there is no such thing as pure 'environmental protection', but rather the systematic encouragement of destructive, or regenerative, relationships. The kind of fortress conservation that has been a staple of modernist environmentalism should be actively questioned. Rights of nature will inevitably work to empower certain groups over others. The choice of which groups, and for what reasons, is crucial. ${ }^{6}$

Rights as representative arrangements steeped in pre-existing power relations allows us to find other allies that may not themselves appeal to the concept of rights, or that of legal personality. For example, the idea of commons (or, as it is also known in the literature, commoning - therefore putting the accent on the process of achieving commons) is present in many forms and in many different cultures. The basic idea, as developed most famously by Elinor Ostrom (1990), is that lands have, in many cultures and in many places, been managed as common goods. Customary law has recognized and enforced this common good status, which always passes through a series of community-determined rules of conduct that ensure the sustainable long-term use of resources (also see Bollier and Helfrich 2019).

The practice of commoning can be seen as a useful bridge between a-modern ontologies in parts of the world that have been put, by modernity itself, in stark opposition to each other. As Tanas and

6 It is important to realize that choosing to not make this choice - and, for example, allowing for universal and wide standing-does not sidestep power relations. Instead, it relegates power to the already most powerful. 
Gutwirth (2021) argue, the Whanganui case has definite similarities to the law of commons in Sardinia, Italy (usi civici). Other such customary laws exist throughout Europe, and throughout the world, without relying on liberal rights at all. Focusing on the importance (indeed, inevitability) of representation allows us to also see practices such as commoning as important allies that may work, in some cases, together with rights of nature. For example, legal entity status may work in order to bring commoners' lands into a form of representation that empowers local communities. But in this case also, the use of the environment is fundamental, and therefore these kinds of arrangements will often not conform to an ecocentric environmental agenda.

Another potential ally is the much-hated idea of corporate personhood. In particular, the corporate structure that separates ownership (vested in the legal fiction of the corporation itself) from management and governance may also work very well in some cases to solve ownership disputes. In Te Urewera, for example, Katherine Sanders (2018) argued that this is exactly what happened. The rights of nature, as minimalist legal entity status, in fact gave ownership of Te Urewera to Te Urewera itself, which now resembles a corporate structure with a board (ensuring governance) and shareholders (enjoying the benefits generated by Te Urewera). It may be that, because of this structure, Te Urewera can become an important political and economic actor, like corporations have through the granting of their legal personality. Because of this, it matters even more who sits on the board and who gets to determine government arrangements. In other words, it matters even more who represents Te Urewera.

This awareness of rights as representation is obvious when looking at the details of Te Urewera and the Whanganui cases. As I have explored in Chapter 4, these are extremely focused on setting up a democratic process of representation that allows Māori autonomy to come forward in previously suppressed ways. Precisely because these are essentially political arrangements, they will also be temporary and prone to changing. This is to say that the Māori fight for greater autonomy is not over with these arrangements, but rather recast on a basis that grants them more power. All rights of nature are political in this sense. Acknowledging this fact allows us to work 
with it and to construct laws that may also have the desired effects in practice. Importantly, it also allows practitioners to question the purpose of nature's rights actively and to perhaps find new purposes that it can ally with.

\section{The Rights of Nature as Movement}

The diversity of theory and practice that I have presented may or may not warrant the claim that the rights of nature constitute a movement. To be sure, homogeneity is not the hallmark of a movement; but it is worth examining more closely the claim that the disparate cases this book has surveyed, as well as others it has not, are all part of the same movement for rights. Questioning this claim is important in order to safeguard diversity and multiplicity wherever it is threatened. There seems to be an increasing capture of diversity for the purpose of molding it into ecotheological orthodoxy and liberal rights expansionism. This is why it is important to be clear about what it may mean to claim that there is a movement, and how that claim may allow, or not, a diversity of views to thrive.

Claiming to be a movement may mean different things. At the most straightforward level, it simply indicates a growing trend, a move towards something, in this case towards rights of nature. At this level of analysis, it is undeniable that these rights are a growing trend. Besides this strictly linguistic definition of movement, there is a vast literature on what are generally called social movements that can be helpful here. I suspect that when advocates claim to be part of a movement, they also mean part of a social movement. This interpretation is warranted by the actions and priorities of certain key organizations, while also being doubtful in some of its senses.

In the relevant literature, there is no commonly accepted definition of what constitutes a social movement. This doesn't mean that anything goes. Instead, the lack of a foolproof definition reflects the malleability and largely informal nature of such movements. Marco Diani, one of the leading scholars in that field, speaks of social movements as having boundaries drawn by "processes of mutual recognition whereby social actors recognize different ele- 
ments as part of the same collective experience and identify some criteria that differentiate them from the rest" (in van Stekelenburg et al 2013). However, this does not mean that a social movement is formed by formal interests that may be in common between different organizations. As he points out, an organization for the protection of birds need not also be part of the environmental movement unless, of course, it has specific ties (organizational and identitybased) with that movement.

Following from the above, the overall narrative within which a particular event, or a particular organization, is embedded, is extremely important for deciding whether something is a movement. Diani gives the example of a protest against industrial pollution in a working-class area. He points out that it could be part of an environmental movement, a class struggle, or a not-in-my-back-yard movement. It all depends on the overall narrative within which it is inscribed and the goals and policies that the narrative endorses and makes possible. This means that it is crucially important to see how different cases are presented, and by which organizations, in order to assess if a movement is indeed taking shape.

Social movements rely on interorganizational networks that present an encompassing narrative and set goals to be pursued. However, unlike in formal organizations, movements are largely informal, and a strong identity component is present. This also implies that movements can be very fluid, change over time, and include a great heterogeneity of views. These may splinter, in the course of time, into separate movements, or else continue coexisting within an overall grander narrative. But if we speak of a movement, the literature tends to agree, we are also speaking of "networks of informal interaction between a plurality of individuals, groups and/or organizations, engaged in cultural or political conflicts, on the basis of shared collective identities" (Diani 1992).

As we have seen earlier, the main rights of nature organizations have indeed been engaged in largely informal interactions that have been decisive for several cases, key among which the Ecuadorian constitution. That experience and its wide publicity have also popularized nature's rights as an idea and diffused it widely. However, that kind of diffusion does not necessarily make a movement since 
the recipients of the idea (as in the Colombian and Indian cases) may or may not share organizational networks and/or collective identities. What is certain is that important organizations are putting a lot of effort into expanding their base and transforming the organization of rights of nature from an elite-driven enterprise into a grassroots one.

Early cases, and especially the most publicized ones, like Ecuador and Bolivia, have been elite driven. In these cases, political and intellectual elites had already decided on a preferred course of action, which was then implemented when a window of opportunity opened up (Kingdon and Stano 1984). CELDF, the most influential organization in the actual writing of legislation to date, ${ }^{7}$ has also driven community initiatives for rights of nature at municipal levels in the United States. Here, too, there has always been a pre-determined goal (of reaching rights of nature), and an increasing effort to diffuse this goal widely and gather community support. This meant that CELDF has been putting a lot of effort into tying community rights, human rights, minority rights and nature's rights into a logical and seamless web.

Whether the rights of nature conform to the scholarly definition of a social movement may, in itself, be of little interest. What I want to show through this short foray into that literature is that there are characteristics that these rights share with social movements, and others that they don't. For example, not all rights for nature have emanated out of an international policy network. The New Zealand cases, for instance, have had a parallel development and, indeed, share little of the ecotheological history. ${ }^{8}$ In terms of the identity of people participating in rights of nature advocacy, this also varies widely, and at this point it is hard to say whether there is such a thing as a shared identity at all. If anything, considering

7 Given its composition, the new Center for Democratic and Environmental Rights (CDER) may as well become equally influential in the future.

8 This does not mean that important actors in the NZ cases had no idea of their history and practice elsewhere. For example, Morris and Ruru (2010) explicitly follow Cristopher Stone's analysis of legal personality and draw an explicit parallel between that Western legal concept and Māori tikanga. 
rights of nature as a movement in this particular historical moment would require a definition of movements as quite encompassing of heterogeneity of identities.

The most important question that arises out of this discussion, as far as I'm concerned, is what the grander narrative that organizes the movement is. If we take our cue from the dominant organizations, then this narrative is undeniably the liberal theory of rights and its expansion. These organizations promote this particular narrative while incorporating all possible cases into it even though there is great diversity of practice. This can be both a tool for further expansion and one for policing how rights of nature may develop. Whether or not advocates in new and different cases subscribe to the ecotheology of rights is important in assessing what kind of movement is burgeoning. Currently, a look at the resources pages displayed by the most important organizations reveals that they list no critical titles, even though these exist. This can be a deep problem for the creation of an inclusive movement.

Some of the theoretical commitments of ecotheology, including the idea that the rights of nature are but the next step in the expanding circle of moral concern, may restrict how future cases develop. If Te Urewera would have indeed developed as part of an international movement, it would have granted Tūhoe the status of guardians, therefore restricting the ways in which Māori jurisprudential traditions may influence current and future governance practices. Other potential innovations would benefit from a wider opening within the growing trend towards rights divergence, and for self-reflection and questioning. The kind of questioning I have in mind is already present in cases that are currently being theoretically elaborated, in preparation for future practical deployment.

For example, a recent article (RiverOfLife et al 2020) proposes that Martuwarra river in Australia be designated a legal person, but it does so in a way that puts indigenous jurisprudence front and center and therefore builds yet another path for the rights of nature to travel through. It proposes, among other innovations, that the right to life be interpreted as connected to the crime of ecocide, itself connected to the internationally recognized crime of genocide. It convincingly argues that ecocide is a way towards genocide, 
a claim that comes directly out of Indigenous experiences of dispossession. ${ }^{9}$ But it does not make this argument based on the liberal expansionism of rights, and this matters greatly in diversifying the theoretical and practical toolkit that legal innovation can propose in the future.

On the strength of the social movement literature, rights of nature both are and aren't a movement at this stage in their development. If it is to become a truly inclusive one, then the organizations currently dominating the field need to adopt, in my view, a much more critical stance towards the orthodoxy that they themselves are helping build. Any movement is as good as the vigilance that allows it to stave off the almost inevitable ossification of its positions. Defending against this inherent danger will allow the rights of nature to evolve and perhaps to overcome their uncomfortable alliance with liberal rights orthodoxy.

9 As Philip Sands showed in East West Street (2016), by uncovering the origins of genocide, this internationally recognized crime stood in contrast to the contemporaneously created "crimes against humanity". The former applies to groups, while the latter to individuals. In this sense, crimes against humanity comes closer to the rights-driven approach explored here, whereas genocide/ecocide would apply to specific groups/biomes. This distinction is worth pursuing further, especially as the crime of ecocide is poised to become increasingly important in international law. Ecocide may well offer a way towards condemning ecological crimes without heavily relying on the category of rights. 